\title{
Sarcopenia prevalence and the quality of life in older adults: A study from Turkey's east
}

\author{
Yaşlı yetişkinlerde sarkopeni prevalansı ve yaşam kalitesi: Türkiye’nin doğusundan \\ bir araştırma \\ Mehmet Efe ${ }^{1}$ \\ Aslı Kılavuz ${ }^{2}$ iD \\ Zeliha Fulden Saraç ${ }^{2}$ \\ Sumru Savaş ${ }^{2}$ \\ ${ }^{1}$ Muş Alparslan University, Department of Gerontology, Muş, Turkey \\ ${ }^{2}$ Ege University Medical Faculty, Division of Geriatrics, Department of Internal Medicine, Izmir, Turkey
}

\begin{abstract}
Aim: Sarcopenia as a geriatric syndrome decreases quality of life and increases functional dependency, hospitalization and mortality. The aim of this study is to investigate the prevalence of sarcopenia among community-dwelling people aged 65 years and older in Muş province and to examine its effects on quality of life.
\end{abstract}

Materials and Methods: In this study we have interviewed 371 community-dwelling older adults. A total of 186 older adults from the rural area and 185 older adults from Muş city center were enrolled in the study. Data was collected through face-to-face interviews conducted in the participants' homes by trained researchers. The presence of sarcopenia, socio-demographic characteristics (place of residence, gender, age), presence of chronic diseases, polypharmacy, body mass index, and quality of life with Short Form-36 were determined. Muscle mass, handgrip strength and gait speed were determined for defining sarcopenia.

Results: The mean age of participants was $72.3 \pm 6.8$ years $(65-100)$ and $46.1 \%$ of them were females. The prevalence of sarcopenia was $11.8 \%$ among older people residing in the rural area whereas the prevalence was $21.6 \%$ among older individuals living in the city center $(p=0.012)$. Sarcopenic patients were older, more underweight, hypertensive, and had lower calf circumference, gait speed, and grip strength in males than non-sarcopenic patients $(p<0.0001, p<0.0001, p=0.005$, $p<0.0001, p=0.001, p<0.0001$, respectively). There were important distinction between sarcopenic individuals and non-sarcopenic individuals in terms of physical function, physical role weakness and emotional role weakness $(p=0.021, p=0.006$ and $p=0.009$, respectively).

Conclusion: Sarcopenia is very common among older adults, especially in the city center, and the presence of sarcopenia has detrimental effects on the quality of life.

Keywords: Aged, sarcopenia, quality of life, prevalence.

ÖZ

Amaç: Sarkopeni; yaşam kalitesini düşüren, fonksiyonel bağımlılığı, mortaliteyi ve hastaneye yatış oranını artıran bir geriatrik sendromdur. Bu çalışma, Muş ilinde toplumda yaşayan 65 yaş ve üzeri yetişkinlerde sarkopeni prevalansını değerlendirmeyi ve yaşam kalitesi üzerindeki etkilerini incelemeyi amaçlamaktadır.

Corresponding author: Mehmet Efe

Muş Alparslan University, Department of Gerontology, Muş,

Turkey

E-mail:m.efe@alparslan.edu.tr 
Gereç ve Yöntem: Bu çalışmada, Muş ilinde toplumda yaşayan toplam 371 katılımcıyla görüşüldü. Çalışmaya katılan yaşlı yetişkinlerin 186'sı Muş ilinin kırsal kesiminden, 185'i il merkezinde yaşamaktaydı. Veriler, katılımcıların evlerinde deneyimli araştırmacılar tarafından yüz yüze görüşme tekniğiyle toplanmıştır. Katıımcılarda sarkopeni varlığı, sosyo-demografik özellikler (yaş, cinsiyet, yaşadığı yer), kronik hastalık varlığı, polifarmasi, vücut kitle indeksi ve SF-36 yaşam kalitesi ölçeği ile yaşam kalitesi değerlendirilmiştir. Sarkopeniyi tanımlamak için yürüyüş hızı, el kavrama gücü ve baldır çevresine göre kas kütlesi belirlenmiştir.

Bulgular: Katıımcıların yaş ortalaması $72,3 \pm 6,8$ yıl (65-100) ve \%46,1'i kadındı. Kırsal alanda yaşayan yaşlı yetişkinlerde sarkopeni prevalansı \%11,8 iken, şehir merkezinde yaşayanlarda \%21,6 idi $(p=0,012)$. Erkek katılımcılardan sarkopenik olanlar, sarkopenik olmayanlara göre daha yaşlı, daha zayıf, hipertansif ve daha düşük baldır çevresi, yürüme hızı ve kavrama gücüne sahipti (sırasıyla, $p<0,0001, p<0,0001, p=0,005, p<0,0001, p=0,001, p<0,0001)$. Sarkopenik bireyler ile sarkopenik olmayan bireyler arasında fiziksel işlev, fiziksel rol zayıflığı ve duygusal rol zayıfığı açısından anlamlı farklııklar saptandı (sırasıyla, $p=0,021, p=0,006$ ve $p=0,009$ ).

Sonuç: Sarkopeni, özellikle şehir merkezinde yaşayan yaşlı yetişkinler arasında daha sık görülmüştür ve sarkopeni varlığının yaşam kalitesi üzerinde olumsuz etkileri vardır.

Anahtar Sözcükler: Yaşlı, sarkopeni, yaşam kalitesi, prevalans.

\section{INTRODUCTION}

Old age is characterized by weakening of vital functions and as well as the loss of the ability to adapt to environmental factors (1). The population aged 65 years and older shows an increase of $5 \%$ per annum in both developed and developing countries (2-4). Sarcopenia is one of the most important geriatric syndromes and refers to a decrease in muscle mass, strength, functionality and performance depending on age (5-8). Thus, older individuals may become dependent on their activities of daily living (9). The quality of life is described as individuals' healthiness, as well as their effectiveness in physical, social and psychological aspects. It is also related to many elements of life such as benefiting from health and educational services, adequate nutrition and protection, participation in daily life, and respectfulness. Accordingly, physical activity and exercise have substantial impact on the quality of life (10). In recent years, there has been a consensus that instruments on quality of life should be multidimensional and include subjective characteristics. Many researchers proposed a comprehensive instrument for areas such as, social function, physical role, physical symptoms and psychological factors, cognitive function, body image and sexual function (11-13).

Considering sensitivity, reliability and validity to change among the scales evaluating the quality of life in people aged 60 and over, it was found that the Short Form-36 (SF-36), EuroQol-5 Dimension (EQ-5D) and Nottingham Health
Profile scales are more sensitive (14-15). The SF-36 is recommended when there is a need to conduct a comprehensive estimation of the health-related quality of life (16). The aim of this study is to investigate the prevalence of sarcopenia and the impact of sarcopenia on the quality of life of older adults in our city.

\section{MATERIALS AND METHODS \\ Study population and design}

This cross-sectional research was performed in Muş province between January 2017 and March 2018. At the time of the study, the number of people aged 65 years and over living in the central district of Muş province was 10737, and the minimum sample size was 371 with a $5 \%$ margin of error and $95 \%$ confidence interval. The names and addresses of all individuals aged 65 and over were taken from local authorities, and individuals were selected by random. A total of 186 older adults from the rural area and 185 older adults from Muş city center were participated in the research. Elimination principle were diabetic foot, cognitive impairment, amputation of lower extremities, not able to walk or perform grip strength. Sociodemographic characteristics of the participants such as age, gender, place of residence and diseases diagnosed by a physician (e.g. hypertension, congestive heart failure, peripheral artery disease, cancer, diabetes mellitus, liver and renal failure) were recorded. The data were collected in the participants' residences using a questionnaire which was developed by the researchers in accordance with the variables. The interviewers 
who collected the data were trained about the study in advance.

\section{Anthropometric measurements}

Individuals were weighed by a digital scale without shoes in light indoor clothes and the heights were measured by a meter fixed on the wall. The body-mass index (BMI) was obtained by dividing the weight $(\mathrm{kg})$ by the square of the length $\left(\mathrm{m}^{2}\right)$. Accordingly, a BMl of $<18.5 \mathrm{~kg} / \mathrm{m}^{2}$ was regarded as low BMI, $18.5-24.9 \mathrm{~kg} / \mathrm{m}^{2}$ as normal, $25-29.9 \mathrm{~kg} / \mathrm{m}^{2}$ as overweight, and $\geq 30 \mathrm{~kg}$ $/ \mathrm{m}^{2}$ as obese (17).

\section{Sarcopenia evaluation}

Sarcopenia was determined based on the diagnosis algorithm of European Working Group on Sarcopenia in Older People (EWGSOP) 2010 consensus (9). Muscle mass, grip strength and gait speed were determined for defining sarcopenia.

Gait speed was measured by using a stopwatch to measure participants' duration of walking for 6.0 meters. The interviewer identified the starting and ending points on a flat surface, ensured that the participant starts from the starting point, and started the time and ended it when the participant went beyond the ending point. The time during which the participant walked 6.0 meters was recorded in seconds. Gait speed of $1 \mathrm{~m} / \mathrm{s}$ and slower was regarded as low walking speed $(9,18)$.

Muscle strength was measured using the Takei T.K.K. digital handgrip dynamometer (Takei Scientific Instruments Co. Ltd, Tokyo, Japan). The highest of the three measured values were taken as the final strength of the dominant hand. The cutoff points in the EWGSOP 2010 consensus paper were used for muscle strength (9). Muscle strength of $<30 \mathrm{~kg}$ for men and $<20$ $\mathrm{kg}$ for women was classified as low.

The muscle mass parameter was measured through the calf circumference measurements. While the participant was sitting with a leg curled up at 90 degrees, the circumference of the widest part of the calf was measured as parallel to the ground with a non-stretched measuring tape. Individuals with a calf circumference of $31 \mathrm{~cm}$ or lower were regarded as having low muscle mass (19). Based on this algorithm, the presence of low muscle mass alone indicates pre-sarcopenia, low muscle strength or low gait speed in addition to low muscle mass shows sarcopenia, and lastly low muscle strength plus low gait speed and low muscle mass demonstrates severe sarcopenia (9).

\section{The quality of life}

The SF-36 consists of 36 items, two primary dimensions, which are physical and mental, and eight sub-scales including physical function, physical role restriction, social function, emotional role restriction, energy, mental health, pain and general health perception (20). Turkish reliability and validity studies were conducted by Pınar in 1995 (21).

\section{Statistical analyses}

The data were analyzed using IBM SPSS 23.0. While reporting descriptive findings, the mean and standard deviations or medians (minimummaximum) of the data obtained through the instruments were presented along with the grouped data frequency distributions where available. Chi-square was considered for the test of qualitative variables, while student-t test and Mann-Whitney $U$ test were performed for quantitative variables and the significance level was accepted as $p<0.05$.

\section{RESULTS}

A total of 191 participants living in the city center and 188 individuals from rural area, 379 individuals in total were contained in the study. Eight participants with the elimination criteria were eliminated from the inquiry. Finally, 371 participants were contained in the analysis. The mean age of the participants was $72.3 \pm 6.8$ years (65-100). According to BMI, 124 participants $(33.4 \%)$ were obese and 130 participants $(35 \%)$ were overweight. Among the participants, 330 of them $(89.9 \%)$ had at least one chronic disease and 275 participants (74.1\%) used at least one drug continuously. The most common chronic diseases were hypertension $(51.5 \%)$, diabetes mellitus $(21.3 \%)$ and congestive heart failure (12.9\%). Peripheral artery disease $(2.2 \%)$, cancer $(1.4 \%)$, liver failure $(2.4 \%)$ and renal failure $(4.9 \%)$ diagnoses were detected only in a few patients, so those diagnoses were not contained in the investigations.

Characteristics of the participants in relation to the presence of sarcopenia are given in Table-1. The pervasiveness of sarcopenia was found to increase particularly with age $(p<0.0001)$. The pervasiveness of sarcopenia was higher among older individuals living in the city center than in the rural area $(p=0.012)$. Sarcopenic patients 
were more underweight, hypertensive, and had lower calf circumference, gait speed and grip strength in males (Table-1). No other significant relationship was found between sarcopenia and in terms of gender, diabetes mellitus, congestive heart failure, the number of drugs, and muscle strength in females as shown in Table-1.

The relationship between the presence of sarcopenia and the subscales of the SF-36 quality of life scale is given in Table-2. Median physical functional scores of non-sarcopenic patients were significantly higher than sarcopenic patients $(p=0.021)$. There were obvious distinction between sarcopenic individuals and non-sarcopenic individuals in terms of role limitation (physical) and role limitation (emotional) $(p=0.006$ and $p=0.009)$ (Table-2).

Table-1. Characteristics of the participants in relation to sarcopenia.

\begin{tabular}{|c|c|c|c|c|c|}
\hline Characteristics & & $\begin{array}{c}\text { Total } \\
(n=371)\end{array}$ & $\begin{array}{c}\text { Sarcopenic } \\
(n=62)\end{array}$ & $\begin{array}{c}\text { Non-sarcopenic } \\
(n=309)\end{array}$ & $p$ \\
\hline \multirow{3}{*}{$\begin{array}{l}\text { Age group, } \\
\text { years, n (\%) }\end{array}$} & $65-74$ & $248(66.8)$ & $27(10.9)$ & $221(89.1)$ & \multirow[t]{3}{*}{$<0.0001^{*}$} \\
\hline & $75-84$ & $96(25.9)$ & $21(21.9)$ & $75(78.1)$ & \\
\hline & $85+$ & $27(7.3)$ & $14(51.9)$ & $13(48.1)$ & \\
\hline \multirow[t]{2}{*}{ Gender, n (\%) } & Female & $171(46.1)$ & $30(17.5)$ & $141(82.5)$ & \multirow[t]{2}{*}{$0.780^{*}$} \\
\hline & Male & $200(53.9)$ & $32(16.0)$ & $168(84.0)$ & \\
\hline \multirow{2}{*}{$\begin{array}{l}\text { Residence } \\
\text { address, n (\%) }\end{array}$} & Rural & 186 & $22(11.8)$ & $164(88.2)$ & \multirow[t]{2}{*}{$0.012^{*}$} \\
\hline & City center & 185 & $40(21.6)$ & $145(78.4)$ & \\
\hline \multirow{3}{*}{$\begin{array}{l}\text { Chronic } \\
\text { diseases, } \\
\text { n (\%) }\end{array}$} & HT & $191(51.5)$ & $42(22.0)$ & $149(78.0)$ & $\mathbf{0 . 0 0 5 ^ { \star }}$ \\
\hline & DM & 79 (21.3) & 12 (15.2) & 67 (84.8) & $0.737^{\star}$ \\
\hline & $\mathrm{CHF}$ & $48(12.9)$ & $10(20.8)$ & 38 (79.2) & $0.410^{*}$ \\
\hline \multirow{5}{*}{$\begin{array}{l}\text { Number of } \\
\text { medications, } \\
\text { n (\%) }\end{array}$} & 0 & $96(25.9)$ & $16(16.7)$ & $80(83.3)$ & \multirow[t]{5}{*}{$0.816^{*}$} \\
\hline & $1-2$ & 148 (39.9) & $23(15.5)$ & $125(84.5)$ & \\
\hline & $3-4$ & $90(24.3)$ & $16(17.8)$ & $74(82.2)$ & \\
\hline & $5-6$ & $27(7.3)$ & $4(14.8)$ & $23(85.2)$ & \\
\hline & 7 and above & $10(2.7)$ & $3(30.0)$ & $7(70.0)$ & \\
\hline \multirow{4}{*}{$\begin{array}{l}\text { Body } \\
\text { composition, } \\
\text { n (\%) }\end{array}$} & Underweight & $8(2.2)$ & $6(75.0)$ & $2(25.0)$ & \multirow[t]{4}{*}{$<0.0001^{\star}$} \\
\hline & Normal & $109(29.4)$ & 37 (33.9) & $72(66.1)$ & \\
\hline & Overweight & $130(35)$ & $18(13.8)$ & $112(86.2)$ & \\
\hline & Obese & $124(33.4)$ & $1(0.8)$ & $123(99.2)$ & \\
\hline $\mathrm{CC}(\mathrm{cm})^{\dagger}$ & & $35.1 \pm 5.2$ & $28.2 \pm 2.3$ & $36.5 \pm 4.5$ & $<0.0001^{\star \star}$ \\
\hline \multirow{2}{*}{$\begin{array}{l}\text { Grip strength } \\
(\mathbf{k g})^{\dagger}\end{array}$} & Female & $15.6 \pm 5.6$ & $14.8 \pm 5.2$ & $15.8 \pm 5.7$ & $0.368^{\star *}$ \\
\hline & Male & $30.8 \pm 10.4$ & $23.46 \pm 9.9$ & $32.2 \pm 9.9$ & $<0.0001^{\star *}$ \\
\hline $\begin{array}{l}\text { Gait speed } \\
(\mathbf{m} / \mathbf{s n})^{\dagger}\end{array}$ & & $0.8 \pm 0.3$ & $0.7 \pm 0.2$ & $0.8 \pm 0.3$ & $0.001^{\star *}$ \\
\hline Low CC, n (\%) & & $67(18.0)$ & $61(91.04)$ & $6(8.95)$ & $<0.0001^{\star}$ \\
\hline $\begin{array}{l}\text { Slow gait speed, } \\
\text { n (\%) }\end{array}$ & & $241(64.9)$ & $51(21.1)$ & $190(78.8)$ & $0.002^{*}$ \\
\hline \multirow{2}{*}{$\begin{array}{l}\text { Low grip } \\
\text { strength, n (\%) }\end{array}$} & Female & $135(78.9)$ & $24(17.7)$ & 111 (82.2) & \multirow{2}{*}{$<0.0001^{\star}$} \\
\hline & Male & 85 (42.5) & $23(27.1)$ & $62(72.9)$ & \\
\hline
\end{tabular}

$\mathrm{HT}$, hypertension; BMI, body mass index; CHF, congestive heart failure; DM, diabetes mellitus; CC, calf circumference. ${ }^{\dagger}$ Values are given as mean \pm standard deviations; ${ }^{;}$Pearson Chi Square Test" "** Mann Whitney-U Test. 
Table-2. Effects of sarcopenia on quality of life according to SF-36 scale.

\begin{tabular}{|c|c|c|c|}
\hline Variables & $\begin{array}{c}\text { Sarcopenic } \\
(\mathrm{n}=62)\end{array}$ & $\begin{array}{l}\text { Non-Sarcopenic } \\
\quad(n=309)\end{array}$ & $\mathbf{p}$ \\
\hline Physical functioning ${ }^{\dagger \dagger}$ & $30(0-100)$ & $40(0-100)$ & $0.021^{*}$ \\
\hline Role limitation-physical $^{\dagger}$ & $16.1 \pm 32.6$ & $26.1 \pm 35.4$ & $0.006^{*}$ \\
\hline Role limitation- emotional $^{\dagger}$ & $16.6 \pm 32.3$ & $29.3 \pm 38.7$ & $0.009^{*}$ \\
\hline Vitality $^{\dagger \dagger}$ & $40(0-100)$ & $45(0-100)$ & $0.074^{\star}$ \\
\hline Mental health ${ }^{\dagger \dagger}$ & $56(16-100)$ & $56(0-100)$ & $0.562^{*}$ \\
\hline Social functioning ${ }^{\dagger \dagger}$ & $50(0-100)$ & $63(0-100)$ & $0.286^{*}$ \\
\hline Bodily pain $^{\dagger \dagger}$ & $45(0-100)$ & $45(0-100)$ & $0.775^{\star}$ \\
\hline General health perception ${ }^{\dagger \dagger}$ & $35(0-100)$ & $40(0-100)$ & $0.051^{*}$ \\
\hline
\end{tabular}

${ }^{\dagger}$ Values are given as mean \pm standard deviations; ${ }^{+\dagger}$ Values are given as medians (minimum-maximum); ${ }^{*}$ Mann Whitney-U Test.

\section{DISCUSSION}

In the scope of this study, 171 female $(46.1 \%)$ and 200 male $(53.9 \%)$ with a mean age of $72.2 \pm$ 6.7 years, a total of 371 individuals aged 65 years and over were interviewed. Their sociodemographic characteristics, chronic disease status, multiple drug use, BMI, presence of sarcopenia and quality of life were examined. Subsequently, the relationship between the quality of life and sarcopenia was investigated. Prevalence of sarcopenia is $5-13 \%$ in adults aged 60 to 70 years, and $11-50 \%$ in adults the age of 80 and over (22). In a study conducted in Belgium, the prevalence of sarcopenia was found to be $8.4-27.6 \%$ in 250 individuals aged 65 years and over who applied for outpatient care in a geriatric clinic (23). In Brazil, the prevalence was found to be $6.1-36.6 \%$ in 132 individuals aged 60 years or older by using different criteria (24). In a study conducted according to EWGSOP criteria in Japan, the prevalence of sarcopenia was found to be $7.5 \%$ in 5104 individuals aged 65 years and older (25). The prevalence of sarcopenia in all older participants was $16.7 \%$ in this study. By advancing age, sarcopenia prevalence increased in our study in accordance with the literature (26-28).

This study has a different characteristic compared to the literature in terms of including participants from both rural and urban areas. The frequency of sarcopenia showed a statistically obvious distinction between individuals living in the two regions. The prevalence of sarcopenia was $11.8 \%$ in individuals living in rural areas, and
$21.6 \%$ in those living in urban areas. Older people living in the rural areas are more active using body muscles at their work, and individuals living in the urban areas may have less physical activity, less exposure to sun, and a diet high in fats and refined carbohydrates. So, the lower sarcopenia prevalence in the rural areas might have resulted from this situation. In accordance with our study, another study involving 205 Brazilian community-dwelling older adults, the pervasiveness of sarcopenia was significantly higher in women living in urban areas than in the rural group (29). In another study, the pervasiveness of sarcopenia was significantly higher in urban areas than in the rural areas (30). Unlike our study, in a recent study from China; sarcopenia was higher in community-dwelling elderly in rural areas (31). That finding may be explained with two facts. First, rural elders in that study suffered from malnutrition or were at risk for malnutrition, which may cause sarcopenia. Second, fewer rural elders performed physical activity than urban elders in that study; therefore, they were more sarcopenic than urban elders. In addition, more rural adults were suffering from osteoarthritis, which could significantly affect normal walking speed (32).

There are studies showing the relationship between hypertension and the presence of sarcopenia. According to a study in Japan, the frequency of hypertension increased the incidence of sarcopenia. In this study, the most common disease among participants was hypertension, and it was revealed that there was a significant relationship with sarcopenia (33). 
The present study revealed a correlation between low BMI and sarcopenia. In several studies, the participants with sarcopenia had lower BMls similar to our study $(31,31-38)$. In another study, higher BMI was found as a risk factor for sarcopenia, which was different from our study (30).

We realized a obvious distinction statistically in the quality of life scores between sarcopenic and non-sarcopenic individuals. In our results, the scores were significantly lower in sarcopenic individuals, especially in the physical functioning subscale. The results of our study were similar to the study by Beaudart et al. (38) with 534 individuals over the age of 65 years. In this study, the authors reported that sarcopenia was particularly influential on poor physical function scores with SF-36-measured quality of life. In another study conducted with 2987 people between the ages of 59-73 by using the SF-36 scale, low hand grip values were related to poor physical health and poor general health perception in men, and in addition to these two domains, significant relationships of physical role difficulties, pain and vitality in women have been revealed (39). In a study conducted with 1397 male individuals aged 50 and over in Korea, the EQ-5D scale was used to measure the quality of life, and a significant relationship was found between sarcopenia and mobility problems and daily living activities (40). Patel et al. (41) reported reduced quality of life scores in sarcopenic patients living in the UK. Sarcopenic individuals had poor self-reported functional domains and general health scores. In our study, a significant relationship was found between sarcopenia and physical functioning score. Kull et al. (42) showed lessened quality of life scores in two areas (i.e. vitality and physical function) of the SF-36 survey in sarcopenic content. Our study showed lower scores in the physical functioning, role-physical, and role-emotional subscales of the SF-36 questionnaire.

There were some limitations of our study. First, we did not use the revised EWGSOP criteria (43), as we preferred to use calf circumference measurement for muscle mass. We did not use Turkish thresholds for calf circumference suggested by Bahat et al. (44) either, because of the limited source of studies using local thresholds for calf circumference. Additionally, especially for obese patients, the value of calf circumference for determining muscle mass is not clear $(45,46)$. However in the region that we performed the study, our resources were available for the relevant assessment method. Besides, the Sarcopenia and Quality of Life tool (47) was not applied in this study as another limitation. On the other hand, our study is the first study investigating sarcopenia and health quality in our region reflecting the characteristics of an eastern city of Turkey which may lead future studies following the present study. Our study needs to be evaluated considering those limitations and strengths.

\section{CONCLUSION}

According to the findings of the present study, the prevalence of sarcopenia was $16.7 \%$ among overall, $17.5 \%$ in women and $16 \%$ in men. The pervasiveness of sarcopenia raised majorly with increasing age. Sarcopenia adversely affected the quality of life in terms of physical functioning, physical and emotional limitations. The rate of sarcopenia in rural areas was lower than in urban centers. Lower BMI values increased the risk of sarcopenia. The diagnosis of sarcopenia, which is associated with mortality, morbidity, physical dependence and low quality of life in the elderly, is of great importance. Sarcopenia that arises as a natural result of aging may accelerate with sedentary life habits. In this context, the sarcopenia process can be slowed down with programs aiming at increasing physical activity in the elderly, especially those living in urban areas. At this point, it is necessary for health professionals to motivate the elderly, and for local authorities to ensure an active life for them and provide a sustainable environment and further studies are required to explore the specific causative factors in this context.

\section{Ethical standards}

The research protocol was approved by the local ethics committee of Muş Alparslan University on June 29, 2016 (Approval Number: 29/06/201603-04). Each participant was informed about the study and signed a consent form.

\section{Conflict of interest}

The authors declare that they have no conflict of interest.

No funds, grants, or other support was received. 


\section{References}

1. Smith AP. The concept of well-being: relevance to nutrition research. British journal of nutrition 2005; 93 (1): 1-5.

2. de Jong N. Nutrition and senescence: Healthy aging for all in the new millennium? Nutrition 2000; 16 (7-8): 537-41.

3. Amine E, Baba N, Belhadj M, et al. Diet, nutrition and the prevention of chronic diseases. World Health Organization technical report series 2003. https://www.who.int/dietphysicalactivity/publications/trs916/en/gsfao_introduction.pdf (Accessed on

4. Heinrich M, Prieto JM. Diet and healthy ageing 2100: will we globalise local knowledge systems? Ageing Res Rev 2008; 7 (3): 249-74.

5. Burton LA, Sumukadas D. Optimal management of sarcopenia. Clin Interv Aging 2010; 5: 217-28.

6. Francesco L, Rosa L, Andrea R, et al. Sarcopenia as a risk factor for falls in elderly individuals: Results from the ilSIRENTE study. Clinical Nutrition 2012; 31 (5): 652-8.

7. Rosenberg IH. Summary comments. The American journal of clinical nutrition 1989; 50 (5): 1231-3.

8. Baumgartner RN, Koehler KM, Gallagher D, et al. Epidemiology of sarcopenia among the elderly in New Mexico. Am J Epidemiol 1998; 147 (8): 755-63.

9. Cruz-Jentoft AJ, Baeyens JP, Bauer JM, et al. Sarcopenia: European consensus on definition and diagnosis. Age Ageing 2010; 39 (4): 412-23

10. Pilar GC, Patricia SOP, José RB, Esther L, Fernando RA. Physical activity and quality of life in older adults in Spain. Medicina Clinica 2004; 123 (16): 606-61.

11. Hickey A, Barker M, McGee H, O'boyle C. Measuring health-related quality of life in older patient populations. Pharmacoeconomics 2005; 23 (10): 971-93.

12. Netuveli G, Blane D. Quality of life in older ages. Brit Med Bull 2008; 85 (1): 113-26.

13. O'boyle CA. Measuring the quality of later life. Philosophical Transactions of the Royal Society of London B: Biological Sciences 1997; 352 (1363): 1871-9.

14. EuroQol Group (1990-12-01). EuroQol--a new facility for the measurement of health-related quality of life. Health Policy (Amsterdam, Netherlands) 16 (3): 199-208.

15. Hunt SM, McEwan T: The development of a subjective health indicator. Soc of Health and Illness 1980; 2 : 231-46.

16. Haywood K, Garratt A, Fitzpatrick R. Quality of life in older people: a structured review of generic selfassessed health instruments. Quality of life Research 2005; 14 (7): 1651-68.

17. Obesity, 2006. Guidance on the Prevention, Identification, Assessment and Management of Overweight and Obesity in Adults and Children. National Institute for Health and Clinical Excellence (NICE) Clinical Guideline 43. NICE, London.

18. Fielding RA, Vellas B, Evans WJ, et al. Sarcopenia: an undiagnosed condition in older adults. Current consensus definition: prevalence, etiology, and consequences. International working group on sarcopenia. $J$ Am Med Dir Assoc 2011; 12 (4): 249-56.

19. Rolland $Y$, Lauwers-Cances V, Cournot M, et al. Sarcopenia, calf circumference, and physical function of elderly women: A cross-sectional study. J Am Geriatr Soc 2003; 51 (8): 1120-4.

20. Ware Jr JE, Sherbourne CD. The MOS 36-item short-form health survey (SF-36): I. Conceptual framework and item selection. Medical care 1992; 30 (6): 473-83.

21. Pinar R. Investigation of Quality of Life and Factors Affecting Quality of Life in Patients with Diabetes Mellitus. IU Institute of Health Sciences, PhD Thesis, Istanbul. 1995.

22. Morley JE. Sarcopenia: Diagnosis and treatment. J Nutr Health A. 2008; 12(7): 452-6.

23. Beaudart C, Reginster J-Y, Slomian J, et al. Estimation of sarcopenia prevalence using various assessment tools. Exp Gerontol 2015; 61:31-7.

24. Pagotto V, Silveira EA. Applicability and agreement of different diagnostic criteria for sarcopenia estimation in the elderly. Arch Gerontol Geriat 2014; 59 (2): 288-94.

25. Yamada M, Nishiguchi S, Fukutani N, et al. Prevalence of sarcopenia in community-dwelling Japanese older adults. J Am Med Dir Assoc 2013; 14 (12): 911-5.

26. Arango-Lopera V, Arroyo P, Gutiérrez-Robledo L, Pérez-Zepeda M. Prevalence of sarcopenia in Mexico City, Eur Geriatr Med 2012; 3 (3): 157-60. 
27. Iannuzzi-Sucich M, Prestwood KM, Kenny AM. Prevalence of sarcopenia and predictors of skeletal muscle mass in healthy, older men and women. The Journals of Gerontology Series A: Biological Sciences and Medical Sciences 2002; 57 (12): 772-7.

28. Martinez BP, Batista AKMS, Gomes IB, Olivieri FM, Camelier FWR, Camelier AA. Frequency of sarcopenia and associated factors among hospitalized elderly patients. Bmc Musculoskel Dis 2015; 16 (1): 108.

29. Mazocco L, Gonzalez MC, Barbosa-Silva TG, Chagas P. Sarcopenia in Brazilian rural and urban elderly women: Is there any difference? Nutrition 2019; 58: 120-4.

30. Pongchaiyakul C, Limpawattana $P$, Kotruchin $P$, Rajatanavin R. Prevalence of sarcopenia and associated factors among Thai population. J Bone Miner Metab 2013; 31 (3): 346-50.

31. Gao L, Jiang J, Yang M, Hao Q, Luo L, Dong B. Prevalence of Sarcopenia and Associated Factors in Chinese Community-Dwelling Elderly: Comparison Between Rural and Urban Areas. J Am Med Dir Assoc 2015; 16 (11): 1003.e1-6.

32. Cruz-Jentoft AJ. Sarcopenia: A clinical review. Rev Clin Gerontol 2013; 23: 267-74

33. Yoshida $D$, Suzuki $T$, Shimada $H$, et al. Using two different algorithms to determine the prevalence of sarcopenia. Geriatr Gerontol Int 2014; 14: 46-51.

34. Nasimi N, Dabbaghmanesh MH, Sohrabi Z. Nutritional status and body fat mass: Determinants of sarcopenia in community-dwelling older adults. Exp Gerontol 2019; 122: 67-73.

35. Tramontano A, Veronese N, Sergi G, et al. Prevalence of sarcopenia and associated factors in the healthy older adults of the Peruvian Andes. Arch Gerontol Geriatr 2017; 68: 49-54.

36. Senior HE, Henwood TR, Beller EM, Mitchell GK, Keogh JW. Prevalence and risk factors of sarcopenia among adults living in nursing homes. Maturitas 2015; 82 (4): 418-23.

37. Han P, Kang L, Guo Q, et al. Prevalence and Factors Associated With Sarcopenia in Suburb-dwelling Older Chinese Using the Asian Working Group for Sarcopenia Definition. J Gerontol A Biol Sci Med Sci 2016; 71 (4): 529-35.

38. Beaudart C, Reginster J-Y, Petermans J, et al. Quality of life and physical components linked to sarcopenia: the SarcoPhAge study. Exp Gerontol 2015; 69: 103-10.

39. Sayer AA, Syddall HE, Martin HJ, Dennison EM, Roberts HC, Cooper C. Is grip strength associated with health-related quality of life? Findings from the Hertfordshire Cohort Study. Age Ageing 2006; 35 (4): 409-15.

40. Go SW, Cha YH, Lee JA, Park HS. Association between sarcopenia, bone density, and health-related quality of life in Korean men. Korean J Fam Med 2013; 34 (4): 281-8.

41. Patel HP, Syddall HE, Jameson K, et al. Prevalence of Sarcopenia in Community-Dwelling Older People in the UK Using the European Working Group on Sarcopenia in Older People (EWGSOP) Definition: Findings from the Hertfordshire Cohort Study (HCS). Age and Ageing 2013; 42 (3): 378-84.

42. Kull M, Kallikorm R, Lember M. Impact of a New Sarco-Osteopenia Definition on Health-RelatedQuality of Life in a Population-Based Cohort in Northern Europe. Journal of Clinical Densitometry 2012; 15 (1): 32-8.

43. Cruz-Jentoft AJ, Bahat G, Bauer J, et al. Sarcopenia: revised European consensus on definition and diagnosis. Age Ageing 2019; 48 (1): 16-31.

44. Bahat G, Saka B, Tufan F, et al. Prevalence of sarcopenia and its association with functional and nutritional status among male residents in a nursing home in Turkey. Aging Male 2010; 13 (3): 211-4.

45. Choi KM. Sarcopenia and sarcopenic obesity. Korean J Intern Med 2016; 31: 1054-60.

46. Barazzoni R, Bischoff S, Boirie Y, et al. Sarcopenic obesity: Time to meet the challenge. Obes Facts 2018; 11: 294-305.

47. Beaudart C, Biver E, Reginster JY, et al. Validation of the SarQoL $®$, a specific health-related quality of life questionnaire for Sarcopenia. Journal of Cachexia, Sarcopenia and Muscle, 2017: 8 (2), 238-44. 